\section{Influence of pH and Etridiazole on Pythium Species}

\author{
Charles S. Krasnow ${ }^{1}$ and Mary K. Hausbeck ${ }^{2,3}$
}

AdDitional INDEX wORDs. poinsettia, geranium, Phytophthora, oomycete

Summary. Pythium root rot (Pythium sp.) is ubiquitous in Michigan greenhouses that produce herbaceous ornamentals, an industry worth $\$ 393$ million in the state. Disease symptoms include stunting, flowering delay, root rot, and death. Fungicides that are highly effective against pythium root rot are limited, and pathogen resistance has been documented. The objectives of this study were to determine the sensitivity of Pythium irregulare, Pythium ultimum, and Pythium aphanidermatum isolates from symptomatic herbaceous greenhouse ornamentals to the fungicide etridiazole and to determine the influence of $\mathrm{pH}$ and etridiazole on Pythium mycelial growth and asexual reproduction. Isolates were tested in vitro for sensitivity to etridiazole by growing the pathogen on amended V8-agar plates sealed in plastic containers to minimize fungicide loss from the vapor phase. The majority of isolates of all three species were sensitive to the fungicide with $\mathrm{EC}_{50}$ (effective concentration resulting in $50 \%$ inhibition of linear growth) values ranging from 0.10 to $5.03 \mu \mathrm{g} \cdot \mathrm{mL}^{-1}$. Two isolates of $P$. irregulare had an $\mathrm{EC}_{90}$ (effective concentration resulting in $90 \%$ inhibition of linear growth) value $>80 \mu \mathrm{g} \cdot \mathrm{mL}^{-1}$. The acidity of the medium influenced the ability of etridiazole to inhibit Pythium mycelial growth and asexual reproduction. Agar plates amended with $1 \mu \mathrm{g} \cdot \mathrm{mL}^{-1}$ etridiazole and adjusted to $\mathrm{pH} 4.5$ limited the mycelial growth of two $P$.

aphanidermatum isolates and two $P$. irregulare isolates by $90 \%$ and $56 \%$, respectively, compared with amended agar at $\mathrm{pH}$ 6.5. Sporangial formation by $P$. aphanidermatum was less frequent on mycelial disks incubated in etridiazoleamended sterile distilled water (SDW) at $\mathrm{pH} 4.5$ than $\mathrm{pH} 6.5(P<0.05) . P$. aphanidermatum zoospore cyst germination was less sensitive to etridiazole than sporangia or mycelial growth; however, the influence of $\mathrm{pH}$ and fungicide on cyst germination was significant $(P<0.01)$. At $250 \mu \mathrm{g} \cdot \mathrm{mL}^{-1}$ etridiazole and solution $\mathrm{pH} 4.5$, zoospore cyst germination was inhibited $99.9 \%$ compared with $94.2 \%$ at $\mathrm{pH}$ 6.5. In a greenhouse experiment, disease symptoms were observed on 'Pinto White' geranium (Pelargonium $\times$ bortorum) in a potting medium infested with $P$. aphanidermatum and adjusted to $\mathrm{pH} 4.5$ or 6.5 ; however, plant health and fresh weight were greater in low $\mathrm{pH}$ potting medium. Etridiazole, applied as a drench at transplant, did not improve control of root rot for plants grown at low $\mathrm{pH}(P>$ 0.05 ). Fresh weight of plants grown in infested potting medium adjusted to $\mathrm{pH} 4.5$ and amended with a single drench of etridiazole $\left(100 \mu \mathrm{g} \cdot \mathrm{mL}^{-1}\right)$ was reduced $20 \%$, statistically similar to the untreated control. Adjusting the acidity of irrigation water at the time of etridiazole application in ebb and flow and flood floor production systems could be beneficial in pythium root rot management of certain ornamental crops if plants have tolerance to low $\mathrm{pH}$.

$\mathrm{P}$ ythium root rot causes significant losses in ornamental greenhouse production in Michigan, an industry worth an estimated $\$ 393$ million (U.S. Department of Agriculture, 2014). Pythium species infect roots and root hairs of ornamental

Department of Plant, Soil, and Microbial Sciences, Michigan State University, East Lansing, MI 48824

The authors thank Samantha Borowski for technical assistance. This research was partially funded through a Cooperative Agreement between the USDA-ARS Plant Protection Research Unit, Ithaca, NY and the Michigan State University Department of Plant, Soil and Microbial Sciences (\#58-8062-5-036).

${ }^{1}$ Former Graduate Research Assistant

${ }^{2}$ Professor

${ }^{3}$ Corresponding author. E-mail: hausbecl@msu.edu. doi: 10.21273/HORTTECH03633-16 plants, causing wilting, stunting, delayed flowering, and plant death. Catastrophic losses can occur if plants develop symptoms near the time of retail sale (Hausbeck et al., 1987; Moorman, 1986). Numerous Pythium species cause disease on ornamental crops; however, P. ultimum, $P$. aphanidermatum, and $P$. irregulare are isolated frequently from symptomatic plants in commercial production (Del Castillo Múnera and Hausbeck, 2016; Moorman et al., 2002). Pythium species are ubiquitous in natural environments, and maintaining production facilities free of the pathogen is difficult. Pathogenic Pythium species were found in irrigation water (Bush et al., 2003; Shokes and McCarter, 1979) and dust from greenhouse walk alleys (Stephens et al., 1983). Soilless potting medium can be conducive to pythium root rot because of limited microbial activity (Bolton, 1977; Stephens and Stebbins, 1985). However, reductions in seedling diseases and root rot after amending potting medium with biological controls have heightened the use of such management tools in ornamental crop production (Lewis and Lumsden, 2001; Thrane et al., 2000). Sanitation and preventive measures remain important to reduce inoculum levels in the greenhouse (Stephens et al., 1983). Additionally, greenhouses may inadvertently purchase plantlets or cuttings that are infected but asymptomatic from propagation greenhouses (Moorman and Kim, 2004; van der Gaag et al., 2001). Infected roots or root mucilage support the production of oospores that may become lodged in greenhouse fixtures and piping (Zheng et al., 2000) and are a source of primary inoculum. Survival of mycelium is also possible in the controlled greenhouse environment (Stanghellini, 1974), making Pythium an intractable problem. Greenhouse operations

\begin{tabular}{llll}
\hline $\begin{array}{l}\text { Units } \\
\text { To convert U.S. to SI, } \\
\text { multiply by }\end{array}$ & U.S. unit & SI unit & $\begin{array}{l}\text { To convert SI to U.S., } \\
\text { multiply by }\end{array}$ \\
\hline 29,574 & $\mathrm{fl} \mathrm{oz}$ & $\mu \mathrm{L}$ & $3.3814 \times 10^{-5}$ \\
29.5735 & $\mathrm{fl} \mathrm{oz}$ & $\mathrm{mL}$ & 0.0338 \\
25.4 & inch(es) & $\mathrm{mm}$ & 0.0394 \\
645.1600 & inch & mm & 0.0016 \\
1 & micron(s) & $\mu \mathrm{m}$ & 1 \\
28.3495 & $\mathrm{oz}$ & $\mathrm{g}$ & 0.0353 \\
28,350 & $\mathrm{oz}$ & $\mathrm{mg}$ & $3.5274 \times 10^{-5}$ \\
0.001 & $\mathrm{ppm}$ & $\mathrm{g} \cdot \mathrm{L}^{-1}$ & 1,000 \\
1 & $\mathrm{ppm}$ & $\mathrm{mg} \cdot \mathrm{L}^{-1}$ & 1 \\
1 & $\mathrm{ppm}$ & $\mu \mathrm{gg} \cdot \mathrm{mL}^{-1}$ & 1 \\
0.001 & $\mathrm{ppm}$ & $\mathrm{mL} \cdot \mathrm{L}^{-1}$ & 1,000 \\
$\left({ }^{\circ} \mathrm{F}-32\right) \div 1.8$ & ${ }^{\circ} \mathrm{F}$ & ${ }^{\circ} \mathrm{C}$ & $\left({ }^{\circ} \mathrm{C} \times 1.8\right)+32$ \\
& & &
\end{tabular}

Hortlechnology · June $201727(3)$ 
that use flood floor or ebb and flow bench systems that recycle irrigation water are at increased risk of spreading Pythium species as multiple ranges may be irrigated in the same day and effectively disperse pathogen propagules (Hoitink, 1991).

The fungicides, mefenoxam [active enantiomer of metalaxyl (Subdue Maxx; Syngenta Crop Protection, Greensborough, NC)] and etridiazole (Terrazole; OHP, Mainland, $\mathrm{PA}$ ), have been used for $\approx 40$ years to manage pythium root rot of ornamental crops (McCain and Byrne, 1966; Moorman and Kim, 2004; Raabe et al., 1981). Historically, these fungicides have provided effective control of pythiaceous organisms when applied as soil drenches (Benson, 1979; Hausbeck and Harlan, 2013; Raabe et al., 1981; Stephens and Stebbins, 1985) or mixed into the potting medium (McCain and Byrne, 1966). Resistance to mefenoxam has developed in greenhouse populations of Pythium and Phytophthora because of the site-specific mode of action of the fungicide and selection pressure from the repeated use of this active ingredient (Del Castillo Múnera and Hausbeck, 2016; Lamour et al., 2003; Moorman et al., 2002). In Michigan, greater than $35 \%$ of Pythium species isolates collected from greenhouses were resistant to mefenoxam (Del Castillo Múnera and Hausbeck, 2016). Control failures have been reported in greenhouses and nurseries (Ferrin and Rohde, 1992; Moorman and Kim, 2004) and may become more common if resistant isolates are accidently moved among greenhouses with prefinished plants and propagative material (Moorman et al., 2002). Greenhouses that recycle irrigation water face additional challenges as resistant isolates may be selected when mefenoxam is applied repeatedly (Ferrin and Rohde, 1992) and sublethal fungicide residues that leach from pots into recirculating irrigation water can enhance disease (Garzón et al., 2011).

Etridiazole is a lipophilic fungicide that contains a heterocyclic nitrogen ring and has specificity toward oomycetes (Lyr, 1995; Vuik et al., 1990). Etridiazole disrupts the lipid structure of cell membranes (Radzuhn and Lyr, 1984) and inhibits respiration by binding to the mitochondrial membrane between cytochromes $\mathrm{b}$ and $\mathrm{c}$ (Halos and Huisman, 1976b). The mode of action of etridiazole is considered multisite as cellular proteins may also be disrupted (Lyr, 1995). Resistance to etridiazole has not been observed in Pythium species (Hausbeck and Harlan, 2013; Jamart et al., 1988; Price and Fox, 1986; Raabe et al., 1981; Stephens and Stebbins, 1985), although mechanisms for tolerance to the fungicide are recognized (Halos and Huisman, 1976a). Rotation of fungicides with different modes of action has been recommended to delay the development of fungicide resistance in Pythium and Phytophthora populations (Ferrin and Rohde, 1992; Hausbeck and Harlan, 2013); however, there are limited numbers of additional fungicide options that effectively control pythium root rot. Recently, labeled fungicides with activity toward phytophthora root rot (Phytophthora sp.), such as fenamidone (Hausbeck and Harlan, 2013), have been determined to be ineffective against pythium root rot in greenhouse trials (Enzenbacher et al., 2011; Santamaria and Uribe, 2013).

Cultural practices that reduce growth and dissemination of Pythium species are important in diseasemanagement programs (Hausbeck and Harlan, 2013; Price and Fox, 1986; Stephens and Stebbins, 1985). Limiting the duration of irrigation in ebb and flow systems reduced pythium root rot of poinsettia (Euphorbia pulcherrima), geranium, and chrysanthemum (Chrysanthemum morifolium) compared with standard irrigation practices (Elmer et al., 2012). Poinsettia grown in a Pythium-infested potting medium adjusted to $\mathrm{pH} 4.0$ 4.5 remained healthy compared with plants grown in an infested potting medium at $\mathrm{pH}$ levels $>5.5$ (Bateman, 1962; Bolton, 1980). Substrate $\mathrm{pH}$ can also influence the effectiveness of certain biocides. Chlorine, a disinfestant widely used in greenhouse production facilities, was the most effective in reducing Streptococcus species growth in an acidic solution (Shannon et al., 1965). The influence of solution $\mathrm{pH}$ on fungicides used to control Pythium species in ornamental production is not fully understood; however, $\mathrm{pH}$ is known to affect fungicide efficacy (Smith et al., 1946; Wolfe et al., 1976).
Pythium root rot continues to cause losses in commercial greenhouses despite routine fungicide use (Hausbeck and Harlan, 2013; Moorman and Kim, 2004), planting resistant cultivars (Chagnon and Bélanger, 1991), and preventive measures (Stephens and Stebbins, 1985), heightening the importance of integrated disease management. Our objectives were to a) determine the sensitivity of $P$. ultimum, $P$. aphanidermatum, and $P$. irregulare isolates from Michigan greenhouses to etridiazole; and b) determine the influence of $\mathrm{pH}$ and etridiazole on P. aphanidermatum and $P$. irregulare growth and asexual reproduction.

\section{Materials and methods}

$P$. aphanidermatum $(n=9), P$. irregulare $(n=14)$, and P. ultimum $(n=14)$ isolates originally recovered from symptomatic floriculture crops in Michigan were selected from the culture collection of M.K. Hausbeck at Michigan State University (Table 1). The isolates were maintained on cornmeal agar [CMA $\left(17 \mathrm{~g} \cdot \mathrm{L}^{-1}\right.$ cornmeal)]. Molten V8 agar [163 $\mathrm{mL} \cdot \mathrm{L}^{-1}$ V8 juice, $3 \mathrm{~g} \cdot \mathrm{L}^{-1}$ calcium carbonate $\left(\mathrm{CaCO}_{3}\right), 16 \mathrm{~g} \cdot \mathrm{L}^{-1}$ agar] was cooled to $\approx 50^{\circ} \mathrm{C}$ and amended with etridiazole (Terrazole $35 \mathrm{WP}$ dissolved in SDW) at concentrations of $0,0.1$, $1.0,2.5$, and $6.2 \mu \mathrm{g} \cdot \mathrm{mL}^{-1}$ a.i. For six isolates of $P$. irregulare, preliminary $\mathrm{EC}_{50}$ values were outside of this range of concentrations. These isolates were additionally tested at $62 \mu \mathrm{g} \cdot \mathrm{mL}^{-1}$ etridiazole. A 7-mm diameter colonized agar plug from the margin of a 2- to 4-d-old CMA culture was placed in the center of an amended plate, and the plates were incubated in the dark at ambient temperature $\left(21 \pm 1{ }^{\circ} \mathrm{C}\right)$ in a plastic chamber that was sealed to minimize the loss of etridiazole to the vapor phase (Ioannou and Grogan, 1984). Radial growth on two axes was measured $3 \mathrm{~d}$ post inoculation. There was one plate per etridiazole concentration for each isolate, and the experiment was conducted three times. Growth inhibition (percent) was calculated by comparing radial growth on amended agar plates with radial growth on nonamended control plates. Amended plates were used 1 to $2 \mathrm{~d}$ after preparing the medium.

P. aphanidermatum isolates 106 and 319 and P. irregulare isolates 125 
Table 1. Isolates of P. aphanidermatum, P. irregulare, and P. ultimum obtained from infected ornamental plants in Michigan, and evaluated in vitro for sensitivity to etridiazole.

\begin{tabular}{|c|c|c|c|}
\hline Isolate no. ${ }^{\mathrm{z}}$ & Pythium species & Host $^{\mathrm{y}}$ & Location $^{\mathrm{x}}$ \\
\hline 106 & P. aphanidermatum & Geranium $(P . \times$ hortorum $)$ & $\mathrm{B}$ \\
\hline 670 & P. aphanidermatum & Geranium & G \\
\hline 672 & P. aphanidermatum & Geranium & G \\
\hline 283 & P. aphanidermatum & Poinsettia (E. pulcherrima) & $\mathrm{D}$ \\
\hline 288 & P. aphanidermatum & Poinsettia & $\mathrm{D}$ \\
\hline 290 & P. aphanidermatum & Poinsettia & $\mathrm{D}$ \\
\hline 292 & P. aphanidermatum & Poinsettia & $\mathrm{D}$ \\
\hline 302 & P. aphanidermatum & Poinsettia & $\mathrm{D}$ \\
\hline 319 & P. aphanidermatum & Poinsettia & $\mathrm{D}$ \\
\hline 108 & P. irregulare & Geranium & $\mathrm{H}$ \\
\hline 115 & P. irregulare & Geranium & $\mathrm{D}$ \\
\hline 125 & P. irregulare & Geranium & $\mathrm{D}$ \\
\hline 464 & P. irregulare & Geranium & $\mathrm{C}$ \\
\hline 468 & P. irregulare & Geranium & $\mathrm{C}$ \\
\hline 667 & P. irregulare & Geranium & G \\
\hline 458 & P. irregulare & Geranium & A \\
\hline 49 & P. irregulare & Poinsettia & $\mathrm{E}$ \\
\hline 94 & P. irregulare & Poinsettia & $\mathrm{B}$ \\
\hline 98 & P. irregulare & Poinsettia & $\mathrm{B}$ \\
\hline 306 & P. irregulare & Poinsettia & $\mathrm{D}$ \\
\hline 308 & P. irregulare & Poinsettia & $\mathrm{D}$ \\
\hline 147 & P. irregulare & Snapdragon (Antirrhinum majus) & $\mathrm{D}$ \\
\hline 149 & P. irregulare & Snapdragon & $\mathrm{D}$ \\
\hline 19 & P. ultimum & Poinsettia & $\mathrm{E}$ \\
\hline 26 & P. ultimum & Poinsettia & $\mathrm{E}$ \\
\hline 46 & P. ultimum & Poinsettia & $\mathrm{E}$ \\
\hline 50 & P. ultimum & Poinsettia & $\mathrm{E}$ \\
\hline 52 & P. ultimum & Poinsettia & $\mathrm{F}$ \\
\hline 56 & P. ultimum & Poinsettia & $\mathrm{F}$ \\
\hline 65 & P. ultimum & Poinsettia & $\mathrm{F}$ \\
\hline 69 & P. ultimum & Poinsettia & $\mathrm{F}$ \\
\hline 76 & P. ultimum & Poinsettia & $\mathrm{F}$ \\
\hline 80 & P. ultimum & Poinsettia & $\mathrm{F}$ \\
\hline 422 & P. ultimum & Poinsettia & $\mathrm{F}$ \\
\hline 424 & P. ultimum & Poinsettia & $\mathrm{F}$ \\
\hline 433 & P. ultimum & Poinsettia & $\mathrm{F}$ \\
\hline 439 & P. ultimum & Poinsettia & $\mathrm{F}$ \\
\hline Total & 37 & & \\
\hline
\end{tabular}

${ }^{\mathrm{z}}$ Isolates selected from the culture collection of M.K. Hausbeck at Michigan State University.

${ }^{y}$ Host plant of original isolation.

${ }^{\mathrm{x}}$ Isolates with the same letter designation were collected from the same greenhouse.

and 147 were used to determine the influence of $\mathrm{pH}$ and etridiazole on Pythium growth inhibition. To determine radial growth inhibition, the $\mathrm{pH}$ of the agar medium was adjusted with sterile $1 \mathrm{~N}$ sodium hydroxide $(\mathrm{NaOH})$ and $1 \mathrm{~N}$ hydrochloric acid $(\mathrm{HCl})$ before autoclaving to obtain CMA at $\mathrm{pH} 4.5$ and 6.5. Adjusting the $\mathrm{pH}$ of CMA to 7 before autoclaving was necessary to obtain a $\mathrm{pH}$ of 6.5 (C.S. Krasnow, unpublished data). Etridiazole was incorporated into molten CMA to achieve final concentrations of $0,0.5,1.0,2.0$, 4.0 , and $8.0 \mu \mathrm{g} \cdot \mathrm{mL}^{-1}$. A $5-\mathrm{mm}$ diameter agar plug of $P$. aphanidermatum or $P$. irregulare from an actively growing CMA culture was transferred to the center of each plate, and the plates were incubated at ambient temperature $\left(21 \pm 1{ }^{\circ} \mathrm{C}\right)$ in a sealed chamber under constant fluorescent light for $3 \mathrm{~d}$. Colony diameter was measured on two axes, and the percentage of growth inhibition was calculated as described. There were two replicate plates per fungicide concentration and $\mathrm{pH}$, and the experiment was conducted three times.

To determine the influence of $\mathrm{pH}$ and etridiazole on sporangial formation and zoospore cyst germination, SDW was buffered with 20 $\mathrm{mL}$ citric acid and dibasic phosphate, adjusted to $\mathrm{pH} 4.5$ or 6.5 with $\mathrm{NaOH}$ or $\mathrm{HCl}$, and amended with etridiazole at $0,0.1,0.5$, and $2.5 \mu \mathrm{g} \cdot \mathrm{mL}^{-1}$. An agar slice $(5 \mathrm{~mm}$ diameter, $0.5-$ $1.0 \mathrm{~mm}$ thickness) was removed from the surface of a 5-mm diameter plug of a 2-d-old CMA culture of $P$. aphanidermatum (106 and 319), placed into a $60-\mathrm{mm}$ petri dish containing $6 \mathrm{~mL}$ of etridiazole-amended solution, and incubated at $30{ }^{\circ} \mathrm{C}$ in the dark for $12 \mathrm{~h}$. The agar slice was removed with forceps to a glass microscope slide and rated for the density of lobate and inflated sporangia at three random $1-\mathrm{mm}^{2}$ focal planes per slice with a compound microscope $(100 \times)$ using a $0-2$ scale, where $0=$ no sporulation, $\mathrm{l}=$ light sporulation $(1-5$ sporangia $/ \mathrm{mm}^{2}$ ), and $2=$ heavy sporulation (6-20 sporangia $/ \mathrm{mm}^{2}$ ). Two agar slices were evaluated per plate with two plates per $\mathrm{pH} \times$ concentration; the experiment was conducted three times.

Zoospores of $P$. aphanidermatum (319) were produced according to the method of Rahimian and Banihashemi (1979). A 5-d-old V8-agar culture was divided into six strips and separated into two sterile $100-\mathrm{mm}$ diameter petri dishes. The dishes were flooded with SDW, incubated at $30{ }^{\circ} \mathrm{C}$ for $24 \mathrm{~h}$, drained, rinsed, and flooded with SDW. After incubation for $10 \mathrm{~h}$, zoospores were enumerated with a hemocytometer. Motile zoospores $\left(1 \times 10^{4}\right.$ in $\left.1 \mathrm{~mL}\right)$ were added to $1 \mathrm{~mL}$ of solution adjusted to a $\mathrm{pH}$ of 4.5 or 6.5 containing etridiazole at $0,50,100$, and $250 \mu \mathrm{g} \cdot \mathrm{mL}^{-1}$ in a $2-\mathrm{mL}$ screwcap vial and incubated for $10 \mathrm{~min}$. The vial was vortexed briefly, and a $100-\mu \mathrm{L}$ aliquot was removed and added to a flask containing $100 \mathrm{~mL}$ SDW. The suspension was immediately filtered through $2.5-\mu \mathrm{m}$ pore-size quantitative filter paper (GE Healthcare, Pittsburgh, PA), and the filter paper was plated onto BARPR (50 ppm benomyl, 100 ppm ampicillin, $30 \mathrm{ppm}$ rifampicin, $200 \mathrm{ppm}$ pentachloronitrobenzene, and $10 \mathrm{ppm}$ rose bengal)-amended CMA. After $\mathrm{l} \mathrm{d}$, the filter paper was removed, and the colonies were enumerated. Two vials per $\mathrm{pH} \times$ concentration were used with three replicates per vial, and the experiment was conducted twice. 
A greenhouse experiment to assess the influence of potting medium $\mathrm{pH}$ and etridiazole on pythium root rot of geranium was conducted. 'Pinto White' geranium was seeded into 288-cell plug flats and grown for 4 weeks in a research greenhouse at Michigan State University. Soillesspeat potting mixture (Suremix Michigan Grower Products, Galesburg, MI) was adjusted to $\mathrm{pH} 4.0$ to 4.5 and 6.5 to 7.0 by periodically adding sulfuric acid $\left(1 \% \mathrm{H}_{2} \mathrm{SO}_{4}\right)$ or potassium hydroxide $(1 \% \mathrm{KOH})$ for 3 weeks before the experiment to permit $\mathrm{pH}$ equilibration. Potting mixture samples were taken weekly, and the acidity was measured ( 1 potting medium:2 SDW) using a glass electrode $\mathrm{pH}$ meter (Mettler-Toledo, Columbus, $\mathrm{OH}$ ). The potting mixture was autoclaved for $45 \mathrm{~min}$ at $121{ }^{\circ} \mathrm{C}$ immediately before the experiment. Millet (Pennisetum glaucum) inoculum (Quesada-Ocampo and Hausbeck, 2010) was prepared by autoclaving millet seed $(100 \mathrm{~g})$, distilled water $(72 \mathrm{~mL})$, and L-asparagine $(0.08 \mathrm{mg})$ in mushroom bags (RJG Sales, Port Richey, FL) twice consecutively, and adding seven 7-mm agar plugs colonized by $P$. aphanidermatum. Infested millet seed was grown under constant fluorescent light for 3 to 4 weeks and mixed weekly before use. Isolates 106 and 319 were used to infest millet singly and were mixed $1: 1(\mathrm{v} / \mathrm{v})$ immediately before the experiment. The geranium seedlings were transplanted into 3 -inch diameter pots containing potting mixture adjusted to $\mathrm{pH} 4.0$ to 4.5 or 6.5 to 7.0 and $3 \mathrm{~g} \cdot \mathrm{L}^{-1}$ Pythiuminfested millet, an inoculum density selected based on previous research on root rot symptom development in geranium (Hausbeck et al., 1989). Control pots received $3 \mathrm{~g} \cdot \mathrm{L}^{-1}$ sterilized millet seeded with sterile V8agar plugs. Etridiazole was applied at transplanting as an $80 \mathrm{~mL} /$ plant drench at $0,10,50$, and $100 \mu \mathrm{g} \cdot \mathrm{mL}^{-1}$, followed by an $80-\mathrm{mL}$ drench of water to improve etridiazole movement into the potting medium. The greenhouse day/night temperatures were $27 / 26^{\circ} \mathrm{C}$; supplemental lighting was provided by sodium lamps for $16 \mathrm{~h}$ per day. Plants were rated for disease severity 4 weeks post inoculation using a $1-5$ scale; $1=$ healthy; $2=$ minor chlorosis and stunting; $3=$ chlorotic or necrotic lower leaves and stunting; $4=$ necrotic lower leaves, stunting, and necrotic stem tissue (black leg) at the soil line; and $5=$ plant death. Plant height and width were measured at planting and at the conclusion of the experiment, and plant volume was determined using the shape of a cylinder to approximate plant size (Enzenbacher et al., 2015). Plants were excised at the soil line, and the aboveground plant fresh weight was recorded. About $10 \%$ of inoculated plants were randomly selected, the roots rinsed, and three water-soaked and symptomatic roots per plant isolated onto BARPR-amended CMA and confirmed as $P$. aphanidermatum based on sporangial morphology (van der Plaats-Niterink, 1981). The trial was arranged as a completely randomized design with 10 plants per treatment and was conducted once.

SAS (version 9.4; SAS Institute, Cary, NC) was used to analyze data from the study. Mycelial growthinhibition data were analyzed with linear regression in PROC REG. The $\mathrm{EC}_{50}$ and $\mathrm{EC}_{90}$ were interpolated from growth inhibition data. Growth inhibition data were transformed to probits, and etridiazole concentration was $\log$-transformed before analysis to straighten the dosage-response curve. The data for the influence of $\mathrm{pH}$ and etridiazole on mycelial growth inhibition, sporangial production, and inhibition of zoospore cyst germination are presented as inhibition relative to the nonamended control plates, and differences were separated with Fisher's protected least significant difference test (LSD; $P=$ 0.05 ) using PROC MIXED. Normality of residual data was assessed using PROC UNIVARIATE. Data from each experiment were pooled before analysis as assumptions for homogeneity of variance were met. Data on plant fresh weight, volume, and disease severity rating were analyzed using PROC MIXED with etridiazole concentration and $\mathrm{pH}$ as fixed effects. There was a significant $\mathrm{pH} \times$ fungicide concentration interaction $(P<0.05)$ so a slice statement was used to test simple main effects. Residual data were analyzed to ensure heteroscedasticity.

\section{Results}

Based on mycelial growth, $P$. irregulare was not as sensitive to etridiazole as $P$. aphanidermatum and $P$. ultimum (Table 2). Mean $\mathrm{EC}_{50}$ values were $2.64,0.97$, and $0.58 \mu \mathrm{g} \cdot \mathrm{mL}^{-1}$ etridiazole for $P$. irregulare, $P$. aphanidermatum, and P. ultimum, respectively. Two $P$. irregulare isolates exhibited a notably reduced sensitivity to etridiazole compared with the other isolates, with $\mathrm{EC}_{90}$ values of 134.0 and $84.8 \mu \mathrm{g} \cdot \mathrm{mL}^{-1}$ (data not shown). The mean slope values for mycelial growth inhibition of $P$. irregulare, $P$. aphanidermatum, and $P$. ultimum were $2.90,2.36$, and 2.34, respectively (data not shown).

Linear mycelial growth of pythium was influenced by the $\mathrm{pH}$ of etridiazole-amended CMA. At CMA pH 4.5 and $\mathrm{l} \mu \mathrm{g} \cdot \mathrm{mL}^{-1}$ etridiazole, there was a $>96 \%$ reduction of mycelial growth of $P$. aphanidermatum isolates compared with the nonamended controls (Table 3 ); growth inhibition was $<70 \%$ of the controls at CMA pH 6.5. Radial growth after $3 \mathrm{~d}$ on $\mathrm{pH} 4.5 \mathrm{CMA}$ at $\mathrm{l} \mu \mathrm{g} \cdot \mathrm{mL}^{-1}$ etridiazole was $<5 \mathrm{~mm}$ for $P$. aphanidermatum isolates and $<25 \mathrm{~mm}$ for $P$. irregulare isolates, compared with $>60 \mathrm{~mm}$ for the controls at both $\mathrm{pH}$ levels (Table 3). The slope of the dosage-response curve for mycelial growth on the log-probit scale was steeper at $\mathrm{pH} 4.5$ than $\mathrm{pH} 6.5$ for $P$. aphanidermatum and $P$. irregulare isolates (Fig. 1), indicating greater inhibition at low $\mathrm{pH}$.

Etridiazole inhibited P. aphanidermatum sporangial production more effectively at low $\mathrm{pH}(P<$ $0.01)$. Sporangia were absent on mycelial disks immersed in a solution at

Table 2. Mean concentration resulting in $\mathbf{5 0 \%}$ and $\mathbf{9 0 \%}$ inhibition of linear growth $\left(\mathrm{EC}_{50}\right.$ and $\mathrm{EC}_{90}$, respectively) for Pythium species grown on etridiazoleamended V8 agar.

\begin{tabular}{llllll}
\hline & \multicolumn{2}{c}{ EC $_{\mathbf{5 0}} \mathrm{z}$} & & \multicolumn{2}{c}{$\mathrm{EC}_{\mathbf{9 0}}$} \\
\cline { 2 - 3 } \cline { 5 - 6 } Pythium species & Mean \pm SD & Range & & Mean \pm SD & Range \\
\hline P. aphanidermatum & $0.97 \pm 0.276$ & $0.55-1.36$ & & $6.89 \pm 3.81$ & $2.68-14.67$ \\
P. irregulare & $2.64 \pm 1.16$ & $0.36-5.03$ & & $25.20 \pm 37.33$ & $6.29-134.02$ \\
P. ultimum & $0.58 \pm 0.86$ & $0.10-3.29$ & & $7.03 \pm 4.70$ & $3.59-20.50$ \\
\hline
\end{tabular}

${ }^{2} \mathrm{EC}_{50}$ and $\mathrm{EC}_{90}$ values interpolated from regression equations describing the dosage-response relationship. 
Table 3. Influence of solution $\mathrm{pH}$ and etridiazole on radial growth of $P$. aphanidermatum and $P$. irregulare isolates on corn meal agar.

\begin{tabular}{|c|c|c|c|c|}
\hline \multirow[b]{2}{*}{ Isolate $^{\mathrm{z}}$} & \multirow[b]{2}{*}{ Pythium species } & \multirow{2}{*}{$\begin{array}{c}\text { Etridiazole concn } \\
\left(\mu \mathrm{g} \cdot \mathrm{mL}^{-1}\right)^{\mathrm{y}}\end{array}$} & \multicolumn{2}{|c|}{ Radial growth $(\mathrm{mm})^{\mathrm{x}}$} \\
\hline & & & $\mathrm{pH} 4.5^{\mathrm{w}}$ & pH 6.5 \\
\hline \multirow{5}{*}{106} & \multirow{5}{*}{ P. aphanidermatum } & 0.0 & 64.0 & $82.0^{*}$ \\
\hline & & 0.5 & 23.8 & - \\
\hline & & 1.0 & 2.2 & $25.7^{*}$ \\
\hline & & 2.0 & 0.0 & $8.4^{*}$ \\
\hline & & 4.0 & 0.0 & $6.7^{*}$ \\
\hline \multirow{7}{*}{319} & \multirow{7}{*}{ P. aphanidermatum } & 8.0 & - & 0.0 \\
\hline & & 0.0 & 77.7 & 82.0 \\
\hline & & 0.5 & 31.4 & - \\
\hline & & 1.0 & 2.5 & $26.5^{*}$ \\
\hline & & 2.0 & 0.0 & $9.8^{*}$ \\
\hline & & 4.0 & 0.0 & $6.2^{*}$ \\
\hline & & 8.0 & - & 0.0 \\
\hline \multirow{5}{*}{125} & \multirow{5}{*}{ P. irregulare } & 0.0 & 81.1 & 82.0 \\
\hline & & 0.5 & 53.5 & - \\
\hline & & 1.0 & 8.5 & $19.5^{*}$ \\
\hline & & 2.0 & 0.2 & $9.8^{*}$ \\
\hline & & 4.0 & 0.0 & $6.1^{*}$ \\
\hline \multirow{7}{*}{147} & \multirow{7}{*}{ P. irregulare } & 8.0 & - & 0.8 \\
\hline & & 0.0 & 82.0 & 82.0 \\
\hline & & 0.5 & 70.3 & - \\
\hline & & 1.0 & 24.7 & $56.7^{*}$ \\
\hline & & 2.0 & 0.0 & $30.8^{*}$ \\
\hline & & 4.0 & 0.0 & $7.9^{*}$ \\
\hline & & 8.0 & - & 0.3 \\
\hline
\end{tabular}

${ }^{\mathrm{z}}$ Isolates selected from the culture collection of M.K. Hausbeck at Michigan State University.

${ }^{\mathrm{y}} 1 \mu \mathrm{g} \cdot \mathrm{mL}^{-1}=1 \mathrm{ppm}$.

${ }^{\mathrm{x}}$ Radial diameter on $\mathrm{pH}$-adjusted corn meal agar (CMA) amended with etridiazole measured on two axes per plate after $3 \mathrm{~d}$ growth. Two plates $/ \mathrm{pH} /$ concentration were used, and the experiment was conducted $3 \times ; 1 \mathrm{~mm}=$ 0.0394 inch.

${ }^{\mathrm{w}} \mathrm{CMA} \mathrm{pH}$ adjusted with $\mathrm{l} \mathrm{N}$ hydrochloric acid or sodium hydroxide before autoclaving and amending with etridiazole.

*Indicates significant difference between $\mathrm{pH}$ treatments at $P<0.05$, according to Fisher's protected LSD test. $-=$ not tested.

pH 4.5 containing $2.5 \mu \mathrm{g} \cdot \mathrm{mL}^{-1}$ etridiazole while sporangia developed in a solution at $\mathrm{pH} 6.5$ (Table 4 ). Zoospores of $P$. aphanidermatum were less sensitive to etridiazole than sporangia and mycelial growth. At 100 $\mu \mathrm{g} \cdot \mathrm{mL}^{-1}$ etridiazole, there was $37.7 \%$ and $2.9 \%$ inhibition of zoospore cyst germination at $\mathrm{pH} 4.5$ and $\mathrm{pH} 6.5$, respectively (Table 5). Cyst germination was inhibited $99.9 \%$ in a $\mathrm{pH} 4.5$ solution containing $250 \mu \mathrm{g} \cdot \mathrm{mL}^{-1}$ etridiazole, but inhibition was less (about $94 \%$ ) in a solution containing the same concentration etridiazole adjusted to pH $6.5(P<0.05)$.

The potting medium $\mathrm{pH}$ had a significant effect on geranium health in the greenhouse experiment $[P<$ 0.001 (Table 6)]. Plants grown in infested potting medium at $\mathrm{pH} 4.5$ remained healthy (average disease severity rating 1.7) but were stunted with chlorotic foliage when grown at $\mathrm{pH}$ 6.5 (average disease severity rating 3.5 , data not shown). Plants grown in potting medium adjusted to $\mathrm{pH} 4.5$ or 6.5 and treated with etridiazole did not differ in root rot symptoms or fresh weight at any fungicide concentration $[P>0.05$ (Table 6)]. However, plants grown in infested potting medium at $\mathrm{pH} 4.5$ and treated with etridiazole had significantly greater plant volume than treated plants at $\mathrm{pH} 6.5[\mathrm{P}<0.05$ (data not shown)]. There was no effect of potting medium $\mathrm{pH}$ on plant health for the noninoculated control plants (data not shown).

\section{Discussion}

Etridiazole has provided effective control of pythium root rot in greenhouse production. Most of the Pythium isolates tested in this study were sensitive to etridiazole in vitro and displayed reduced mycelial growth at concentrations $<1.0 \mu \mathrm{g} \cdot \mathrm{mL}^{-1}$. The inhibition levels observed were similar to results with other Pythium and
Phytophthora species (Benson, 1979; Ioannou and Grogan, 1984; Jamart et al., 1988). P. parasitica and $P$. cinnamomi mycelial growth and sporangial formation had $\mathrm{EC}_{50}$ values $<\mathrm{l} .0 \mu \mathrm{g} \cdot \mathrm{mL}^{-1}$ etridiazole (Benson, 1979; Ioannou and Grogan, 1984). Price and Fox (1986) reported similar etridiazole sensitivity for a $P$. irregulare isolate from Australian soil with an $\mathrm{EC}_{50}$ value $<\mathrm{l} .0 \mu \mathrm{g} \cdot \mathrm{mL}^{-1}$ and $86 \%$ mycelial growth inhibition at 10 $\mu \mathrm{g} \cdot \mathrm{mL}^{-1}$. An isolate of $P$. irregulare from ivy (Hedera sp.) had $\mathrm{EC}_{50}$ values of 3.44 and $0.28 \mu \mathrm{g} \cdot \mathrm{mL}^{-1}$ for mycelial growth and oospore formation, respectively, on etridiazole-amended CMA (Jamart et al., 1988). The growth of some $P$. irregulare isolates in the current study at $>50 \mu \mathrm{g} \cdot \mathrm{mL}^{-1}$ etridiazole and detection of $\mathrm{EC}_{90}$ values of 84.8 and $134.0 \mu \mathrm{g} \cdot \mathrm{mL}^{-1}$ for two isolates of this species suggest that there may be diversity in etridiazole sensitivity of $P$. irregulare from Michigan greenhouses. A limited number of $P$. irregulare isolates were tested in previous studies, and baseline threshold values for etridiazole sensitivity were not established (Jamart et al., 1988; Price and Fox, 1986). Including Pythium isolates collected from ornamental crops in multiple production regions and years in future in vitro fungicide screening would provide meaningful comparisons for Michigan isolates.

Even though etridiazole is one of the primary fungicides used in nursery and ornamental crop production to manage root rot caused by Pythium and Phytophthora species (Benson, 1979; Hausbeck and Harlan, 2013; McCain and Byrne, 1966; Raabe et al., 1981), the level of control can be variable. A single drench of etridiazole at $222 \mu \mathrm{g} \cdot \mathrm{mL}^{-1}$ did not provide control of phytophthora root rot ( $P$. cinnamomi) of azalea (Rhododendron obtusum), although four drenches at that rate or a single drench at $444 \mu \mathrm{g} \cdot \mathrm{mL}^{-1}$ effectively limited the disease (Benson, 1979). Etridiazole prevented phytophthora root rot (P. nicotianae) of tomato (Solanum lycopersicum) when incorporated into potting soil at 250 $\mu \mathrm{g} \cdot \mathrm{mL}^{-1}$ in a greenhouse study (Ioannou and Grogan, 1984), and a single drench of etridiazole at 100 $\mu \mathrm{g} \cdot \mathrm{mL}^{-1}$ reduced root rot of larkspur (Delphinium sp.) to $<5 \%$ (Bloch et al., 1976). Etridiazole limited symptoms 
of geranium root rot at 50 and 100 $\mu \mathrm{g} \cdot \mathrm{mL}^{-1}$ in this Michigan study; however, applying etridiazole at a greater rate $\left(\right.$ labeled rate $=92-262 \mu \mathrm{g} \cdot \mathrm{mL}^{-1}$ ) may improve disease control.

In greenhouse experiments using ebb and flow systems, control of pythium root rot by etridiazole has been variable (Jamart et al., 1988; Sanogo and Moorman, 1993), and Pythium species were recovered from
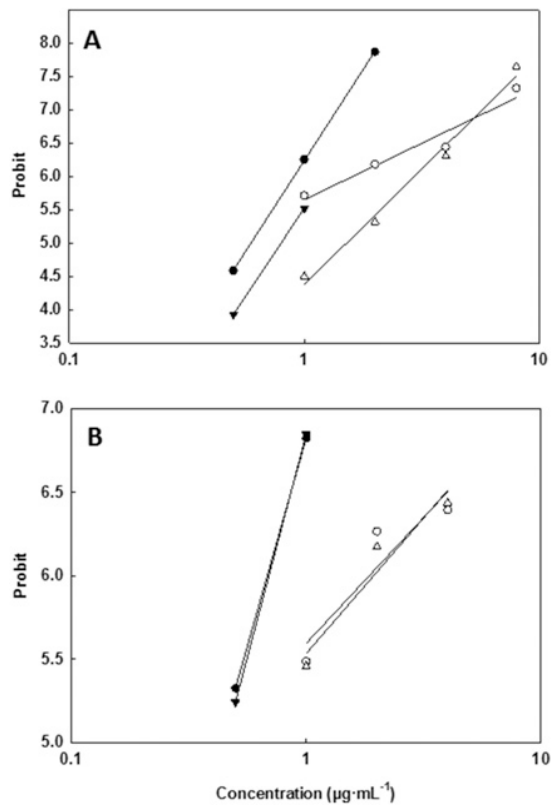

Fig. 1. Dosage-response curves for (A) Pythium irregulare isolates 125 (O) and $147(\Delta)$ and (B) $P$. aphanidermatum isolates $106(\mathrm{O})$ and $319(\Delta)$ on etridiazole-amended corn meal agar adjusted to $\mathrm{pH} 4.5$ (shaded) or 6.5 (open). Radial growth was determined on two axes of each petri plate after $3 \mathrm{~d}$. Each data point is the mean of six replicate plates; $1 \mu \mathrm{g} \cdot \mathrm{mL}^{-1}=1 \mathrm{ppm}$. diseased root tissue when fungicide and zoospore or mycelial inoculum were added consecutively to the recirculating irrigation water (Sanogo and Moorman, 1993; S. Jeon and C.S. Krasnow, unpublished data). The relatively low sensitivity of $P$. aphanidermatum zoospores to etridiazole observed in the current study suggests that these propagules may not be killed when infested recirculating irrigation water is treated with the fungicide. Etridiazole is not mobile in the potting medium and soil (Helling et al., 1974; King and Zentmyer, 1979), and fungicide effectiveness in flood floor and ebb and flow production systems may be affected only if the roots in the lower region of pots are protected when etridiazole is applied in the irrigation water. Conceivably, zoospores or cysts present in fungicide-treated irrigation water could enter pots from the base during irrigation and move with capillary force to roots and potting medium with an ineffective concentration of fungicide. Additionally, etridiazole concentration in recirculating irrigation water is likely diluted by the periodic addition of untreated water to holding tanks (Themann et al., 2002 ) or by volatilization (Ioannou and Grogan, 1984) and may affect disease control during the 1 -month labeled application interval.

Inhibition of radial growth and asexual reproduction of Pythium species by etridiazole was influenced by $\mathrm{pH}$ in this study; however, the mechanisms responsible for inhibition at low $\mathrm{pH}$ were not determined in the study. Solution $\mathrm{pH}$ may directly affect the stability of a fungicide (Wolfe et al., 1976) or the degree of

Table 4. Influence of solution $\mathrm{pH}$ and etridiazole on $P$. aphanidermatum sporangial formation for each of the two isolates.

\begin{tabular}{|c|c|c|c|c|}
\hline \multirow{3}{*}{$\begin{array}{l}\text { Etridiazole concn } \\
\left(\mu \mathrm{g} \cdot \mathrm{mL}^{-1}\right)^{\mathrm{z}}\end{array}$} & \multicolumn{4}{|c|}{ Sporangial formation $(0-2 \text { scale })^{\mathrm{y}}$} \\
\hline & \multicolumn{2}{|c|}{ Isolate $106^{x}$} & \multicolumn{2}{|c|}{ Isolate 319} \\
\hline & $\mathrm{pH} 4.5$ & pH 6.5 & $\mathrm{pH} 4.5$ & $\mathrm{pH} 6.5$ \\
\hline 0 & 1.8 & $2.0^{*}$ & 1.5 & $2.0^{*}$ \\
\hline 0.1 & 1.6 & 1.2 & 1.6 & $2.0^{*}$ \\
\hline 0.5 & 0.3 & 1.0 & 0.8 & $1.9^{*}$ \\
\hline 2.5 & 0.0 & 0.1 & 0.0 & 0.1 \\
\hline
\end{tabular}

${ }^{\mathrm{z}} \mathrm{l} \mu \mathrm{g} \cdot \mathrm{mL}^{-1}=1 \mathrm{ppm}$.

${ }^{\mathrm{y}}$ Density of sporangia at three random $1-\mathrm{mm}^{2}\left(0.0016 \mathrm{inch}^{2}\right)$ focal planes of a $5-\mathrm{mm}(0.2 \mathrm{inch})$ mycelial disk soaked in $\mathrm{pH}$-adjusted solution amended with etridiazole at each concentration estimated using a $0-2$ scale, where $0=$ no sporulation, $1=$ light sporulation $\left(1-5\right.$ sporangia $\left./ \mathrm{mm}^{2}\right)$, and $2=$ heavy sporulation $\left(6-20\right.$ sporangia $\left./ \mathrm{mm}^{2}\right)$. Values represent the mean of six mycelial disks; 1 sporangium $/ \mathrm{mm}^{2}=645.1600$ sporangia/inch ${ }^{2}$.

${ }^{\mathrm{x}}$ Isolate 106 and 319 refer to isolate designation from the culture collection of M.K. Hausbeck at Michigan State University.

${ }^{*}$ Indicates significant difference between $\mathrm{pH}$ treatments at $P<0.05$, according to Fisher's protected LSD test. ionization of the toxophore (Smith et al., 1946). Captan, a fungicide used to control pythium root rot on some crops in greenhouses, hydrolyzes to nonfungitoxic compounds at alkaline $\mathrm{pH}$ (Wolfe et al., 1976), and Spergon (tetra-chloro-p-benzoquinone) seed treatment was least inhibitory to $R h i$ zoctonia solani in alkaline soil as a result of chemical conversion of the fungicide (Kelman, 1947). Uptake of 2,5-dimercapto-1,3,4-thiadiazole homologs by Monolinia fructicola conidia was $2 \times$ greater at $\mathrm{pH} 1.5$ than at $\mathrm{pH} 6.0$ (Somers, 1958). The fungicide homologs were almost completely unionized $(99.9 \%)$ at low $\mathrm{pH}$, which might have improved cellular penetration and pathogen inhibition (Lukens, 1971; Somers, 1958). Low $\mathrm{pH}$ may indirectly affect inhibition by affecting fungicide solubility (Buchenauer and Erwin, 1972). Benomyl and benzimidiazole were more effective at reducing verticillium wilt (Verticillium dabliae) of cotton (Gossypium hirsutum) when applied as a drench in acidic solution than at alkaline $\mathrm{pH}$ levels (Buchenauer and Erwin, 1972). Greater water solubility of these fungicides at low $\mathrm{pH}$ increased uptake by cotton plants, improving disease control. However, the effect of benomyl drenches on cylindrocladium root and petiole rot of lily (Spathiphyllum sp.) was not influenced by the potting medium $\mathrm{pH}[\mathrm{pH}$ 3.8-7.0 (Chase and Poole, 1987)]. Additionally, the $\mathrm{pH}$ of V8 agar medium $(\mathrm{pH}$ 4.5-8.0) did not influence mefenoxam, dimethomorph, or fluopicolide inhibition of Phytophthora capsici mycelial growth (C.S. Krasnow, unpublished data). Additional testing is necessary to determine the effect of $\mathrm{pH}$ on other fungicides and biological control agents labeled for pythium root rot control in greenhouses.

Growing plants in potting medium maintained at low $\mathrm{pH}$ has been recommended to control pythium root rot of poinsettia (Bateman, 1962; Bolton, 1980) and in nursery production to control Phytophthora species (Blaker and Macdonald, 1983). In a hydroponic growing system, greater control of pythium root rot of tomatoes was realized when the nutrient solution was maintained at pH 4.5-5.0 compared with pH 6.06.5 as a result of reduced zoospore motility and attachment to roots; 
Table 5. Influence of solution $\mathrm{pH}$ and etridiazole on $P$. aphanidermatum zoospore cyst germination inhibition.

\begin{tabular}{lcc}
\hline & \multicolumn{2}{c}{ Zoospore cyst germination inhibition $(\%)^{\mathrm{y}}$} \\
\cline { 2 - 3 } Etridiazole concn $\left(\boldsymbol{\mu g} \cdot \mathrm{mL}^{-1}\right)^{\mathrm{z}}$ & $\mathrm{pH} \mathrm{4.5}$ & $\mathrm{pH} \mathrm{6.5}$ \\
\hline 50 & 7.2 & 0.0 \\
100 & 37.7 & $2.9^{*}$ \\
250 & 99.9 & $94.2^{*}$ \\
\hline
\end{tabular}

${ }^{\mathrm{z}} 1 \mu \mathrm{g} \cdot \mathrm{mL}^{-1}=1 \mathrm{ppm}$.

${ }^{\mathrm{y}}$ Zoospore cyst germination inhibition (percent) of $P$. aphanidermatum (319) zoospores after the addition to fungicide-amended solution adjusted to $\mathrm{pH} 4.5 \mathrm{or} \mathrm{pH} 6.5$, filtering the zoospores on $2.5 \mu \mathrm{m}$ (micron) filter paper, plating on benomyl, pentachloronitrobenzene, ampicillin, rifampicin, and rose bengal-amended corn meal agar and determining the reduction in cfu per milliliter compared with the nonamended control plates.

*Indicates significant difference between $\mathrm{pH}$ treatments at $P<0.05$, according to Fisher's protected LSD test.

Table 6. Influence of potting medium $\mathrm{pH}$ and etridiazole on pythium root rot of geranium.

\begin{tabular}{ccc}
\hline & \multicolumn{2}{c}{ Reduction in plant fresh wt $(\%)^{\mathrm{y}}$} \\
\cline { 2 - 3 } Etridiazole concn $\left(\boldsymbol{\mu g} \cdot \mathrm{mL}^{-1}\right)^{\mathrm{z}}$ & $\mathrm{pH} \mathrm{4.5^{ \textrm {x } }}$ & $\mathrm{pH} \mathrm{6.5}$ \\
\hline 0 & 22.0 & $70.8^{*}$ \\
10 & 30.0 & 43.8 \\
50 & 26.0 & 22.9 \\
100 & 20.0 & 25.0 \\
\hline
\end{tabular}

${ }^{\mathrm{z}} 1 \mu \mathrm{g} \cdot \mathrm{mL}^{-1}=1 \mathrm{ppm}$.

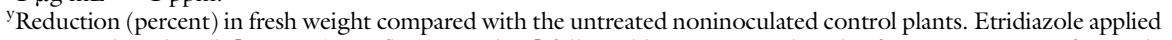
as a transplant drench $[80 \mathrm{~mL}(2.7 \mathrm{lfloz})$ per plant] followed by an $80-\mathrm{mL}$ drench of water to improve fungicide movement into the potting medium. Means represent a single greenhouse experiment with 10 plants/treatment.

${ }^{x}$ Potting medium $\mathrm{pH}$ adjusted with sulfuric acid or potassium hydroxide for 3 weeks before the experiment.

*Indicates significant difference between $\mathrm{pH}$ treatments at $P<0.05$, according to Fisher's protected LSD test.

plant health and yield were unaffected in uninfested nutrient solution maintained at a low $\mathrm{pH}$ (Huang and $\mathrm{Tu}$, 1998). Geranium plant health did not appear to be affected by low $\mathrm{pH}$ potting medium in the present study, similar to poinsettia that remained healthy when grown in potting medium adjusted to $\mathrm{pH} 4.0-4.5$ (Bateman 1962; Bolton 1980). However, Biernbaum et al. (1988) reported iron and manganese toxicity in herbaceous ornamentals grown at low $\mathrm{pH}$, and soilless potting medium is typically maintained at pH 5.5-6.0 in commercial greenhouses to optimize nutrient uptake (Biernbaum et al., 1988; Warncke and Krauskopf, 1983).

In this study, the growth of all three Pythium species was reduced by etridiazole at an acidic $\mathrm{pH}$. The influence of low $\mathrm{pH}$ and etridiazole on Pythium species highlights the importance of monitoring water acidity when etridiazole is applied with irrigation water in flood floor or ebb and flow production systems. Etridiazole may provide insufficient control of root rot when applied in irrigation water maintained near a neutral $\mathrm{pH}$. Improvements in integrated Pythium management may be realized if irrigation water acidity can be augmented without adversely affecting plant health. Tolerance of greenhouse ornamentals to extended periods of low $\mathrm{pH}$ should be tested further.

\section{Literature cited}

Bateman, D.F. 1962. Relation of soil pH to development of poinsettia root rot. Phytopathology 52:559-566.

Benson, D.M. 1979. Efficacy and in vitro activity of two systemic acylalanines and ethazole for control of Phytophthora cinnamomi root rot of azalea (Rhododendron obtusum). Phytopathology 69:174-178.

Biernbaum, J.A., W.H. Carlson, C. Shoemaker, and R. Heins. 1988. Low pH causes iron and manganese toxicity. Greenhouse Grower 6(3):92-93, 96-97.

Blaker, N.S. and J.D. Macdonald. 1983. Influence of container medium $\mathrm{pH}$ on sporangium formation, zoospore release, and infection of rhododendron by Phytophthora cinnamomi. Plant Dis. 67:259-263.

Bloch, E.D., R.D. Raabe, and J.H. Hurlimann. 1976. Control of pythium root rot of larkspur. Plant Dis. Rptr. 60:600-601.

Bolton, A. 1977. The severity of root rot and persistence of Pythium splendens in geranium cuttings grown in soilless mixtures. Can. J. Plant Sci. 57:87-92.
Bolton, A. 1980. Effects of temperature and $\mathrm{pH}$ of soilless media on root rot of poinsettia caused by Pythium aphanidermatum. Can. J. Plant Pathol. 2:83-85.

Buchenauer, H. and D. Erwin. 1972. Control of verticillium wilt of cotton by spraying with acidic solutions of benomyl, methyl 2-benzimidazole carbamate, and thiabendazole. J. Phytopathol. 75:124-139.

Bush, E.A., C. Hong, and E.L. Stromberg. 2003. Fluctuations of Phytophthora and Pythium spp. in components of a recycling irrigation system. Plant Dis. 87:15001506.

Chagnon, M. and R. Bélanger. 1991. Tolerance in greenhouse geraniums to Pythium ultimum. Plant Dis. 75:820-823.

Chase, A. and R. Poole. 1987. Effects of potting medium $\mathrm{pH}$ and air temperature on severity of cylindrocladium root and petiole rot of Spathiphyllum sp. Plant Dis. 71:509-511.

Del Castillo Múnera, J. and M.K. Hausbeck. 2016. Characterization of Pythium species associated with greenhouse floriculture crops in Michigan. Plant Dis. 100:569-576.

Elmer, W., M. Gent, and R. McAvoy. 2012. Partial saturation under ebb and flow irrigation suppresses pythium root rot of ornamentals. Crop Prot. 33:29-33.

Enzenbacher, T., R. Naegele, and M. Hausbeck. 2015. Susceptibility of greenhouse ornamentals to Phytophthora capsici and P. tropicalis. Plant Dis. 99:1808-1815.

Enzenbacher, T.B., H. Hausbeck, and B. Harlan. 2011. Evaluation of registered and experimental fungicides for control of pythium root rot of geranium, 2010. Plant Dis. Mgt. Rpt. 5:OT001.

Ferrin, D. and R. Rohde. 1992. In vivo expression of resistance to metalaxyl by a nursery isolate of Phytophthora parasitica from Catharanthus roseus. Plant Dis. 76:82-84.

Garzón, C.D., J.E. Molineros, J.M. Yánez, F.J. Flores, M. del Mar JiménezGasco, and G.W. Moorman. 2011. Sublethal doses of mefenoxam enhance pythium damping-off of geranium. Plant Dis. 95:1233-1238.

Halos, P.M. and O. Huisman. 1976a. Mechanism of tolerance of Pythium species to ethazol. Phytopathology 66:152-157.

Halos, P.M. and O. Huisman. 1976b. Inhibition of respiration in Pythium spp. by ethazol. Phytopathology 66:158164.

Hausbeck, H. and B. Harlan. 2013. Pythium root rot in the greenhouse. 8 Sept. 2016. <http://msue.anr.msu.edu/news/ pythium_root_rot_in_the_greenhouse $>$. 
Hausbeck, M., C. Stephens, and R. Heins. 1989. Damping off, root rot, and lower stem rot of seed-propagated geraniums caused by Pythium ultimum. Plant Dis. 73:625-627.

Hausbeck, M.K. and B.R. Harlan. 2013. Evaluation of fungicides for control of pythium root rot of poinsettia, 2011. Plant Dis. Mgt. Rpt. 7:OT029.

Hausbeck, M.K., C.T. Stephens, and R.D. Heins. 1987. Variation in resistance of geranium to Pythium ultimum in the presence or absence of silver thiosulphate. HortScience 22:940-944.

Helling, C., D.G. Dennison, and D. Kaufman. 1974. Fungicide movement in soils. Phytopathology 64:1091-1100.

Hoitink, H.A.J. 1991. Transmission of plant pathogens in an ebb and flood system. Ohio Florist Assn. Bul. 742:5-9.

Huang, R. and J. Tu. 1998. Effects of hydrogen ion concentration and temperature on attachment of zoospores of Pythium aphanidermatum to tomato roots. Mededelingen-Faculteit Landbouwkundige en Universiteit Gent 63 (3a):855-859.

Ioannou, N. and R.G. Grogan. 1984. Control of phytophthora root rot of processing tomato with ethazol and metalaxyl. Plant Dis. 68:429-435.

Jamart, G., G.d. Prest, and O. Kamoen. 1988. Control of Pythium spp. on ornamental plants in a nutrient-film system. Mededelingen-Faculteit Landbouwkundige en Rijksuniversiteit Gent 53:625-634.

Kelman, A. 1947. The effect of hydrogenion concentration on the toxicity of Spergon. Phytopathology 37:12.

King, G.D. and G.A. Zentmyer. 1979. Effectiveness of ethazole for control of Phytophthora cinnamomi. Phytopathology 69:917.

Lamour, K.H., M.L. Daughtrey, D.M. Benson, J. Hwang, and M.K. Hausbeck. 2003. Etiology of Phytophthora drechsleri and $P$. nicotianae ( $=P$. parasitica) diseases affecting floriculture crops. Plant Dis. 87:854-858

Lewis, J. and R. Lumsden. 2001. Biocontrol of damping-off of greenhousegrown crops caused by Rhizoctonia solani with a formulation of Trichoderma spp. Crop Prot. 20:49-56.

Lukens, R.J. 1971. Chemistry of fungicidal action. Molecular biology, biochemistry and biophysics, vol. 10 . Springer-Verlag, New York, NY.

Lyr, H. 1995. Modern selective fungicides: Properties, applications, mechanisms of action. Gustav Fischer Verlag, New York, NY.

McCain, A. and T. Byrne. 1966. Chemical control of pythium root rot in ornamentals with Dexon and Terrazole. Calif. Agr. 20(5):14-16.

Moorman, G. 1986. Increased plant mortality caused by pythium root rot of poinsettia associated with high fertilization rates. Plant Dis. 70:160-162.

Moorman, G., S. Kang, D. Geiser, and S. Kim. 2002. Identification and characterization of Pythium species associated with greenhouse floral crops in Pennsylvania. Plant Dis. 86:1227-1231.

Moorman, G. and S. Kim. 2004. Species of Pythium from greenhouses in Pennsylvania exhibit resistance to propamocarb and mefenoxam. Plant Dis. 88:630-632.

Price, T. and P. Fox. 1986. Studies on the behaviour of furalaxyl on pythiaceous fungi and cucumbers in recirculating hydroponic systems. Austral. J. Agr. Res. 37:65-77.

Quesada-Ocampo, L.M. and M.K. Hausbeck. 2010. Resistance in tomato and wild relatives to crown and root rot caused by Phytophthora capsici. Phytopathology 100:619-627.

Raabe, R., J. Hurlimann, and T. Byrne. 1981. Chemical and biological approaches to control of pythium root rot of poinsettia. Calif. Plant Pathol. 52:5-8.

Radzuhn, B. and H. Lyr. 1984. On the mode of action of the fungicide etridiazole. Pestic. Biochem. Physiol. 22:14-23.

Rahimian, M. and Z. Banihashemi. 1979. A method for obtaining zoospores of Pythium aphanidermatum and their use in determining cucurbit seedling resistance to damping-off. Plant Dis. Rptr. 63:658-661.

Sanogo, S. and G.W. Moorman. 1993. Transmission and control of Pythium aphanidermatum in an ebb-and-flow subirrigation system. Plant Dis. 77:287-290.

Santamaria, L. and G. Uribe. 2013. Fungicide efficacy for management of pythium root rot, 2013. Plant Dis. Mgt. Rpt. 9:OT005.

Shannon, E., W. Clark, and G. Reinbold. 1965. Chlorine resistance of enterococci. J. Milk Food Technol. 28:120-123.

Shokes, F. and S. McCarter. 1979. Occurrence, dissemination, and survival of plant pathogens in surface irrigation ponds in southern Georgia. Phytopathology 69:510-516.

Smith, F.G., J. Walker, and W. Hooker. 1946. Effect of hydrogen-ion concentration on the toxicity to Colletotrichum circinans (Berk.) Vogl. of some carboxylic acids, phenols, and crucifer extracts. Amer. J. Bot. 33:351-356.

Somers, E. 1958. The uptake of a homologous series of fungicides by plant tissue and fungal spores. Can. J. Bot. 36:997-1009.

Stanghellini, M.E. 1974. Spore germination, growth and survival of Pythium in soil. Proc. Amer. Phytopathol. Soc. 1:211-214.

Stephens, C., L. Herr, A. Schmitthenner, and C. Powell. 1983. Sources of Rhizoctonia solani and Pythium spp. in a bedding plant greenhouse. Plant Dis. 67:272-275.

Stephens, C. and T. Stebbins. 1985. Control of damping-off pathogens in soilless container media. Plant Dis. 69:494-496.

Themann, K., S. Werres, H.-A. Diener, and R. Lüttmann. 2002. Comparison of different methods to detect Phytophthora spp. in recycling water from nurseries. J. Plant Pathol. 108:41-51.

Thrane, C., D.F. Jensen, and A. Tronsmo. 2000. Substrate colonization, strain competition, enzyme production in vitro, and biocontrol of Pythium ultimum by Trichoderma spp. isolates Pl and T3. Eur. J. Plant Pathol. 106:215-225.

U.S. Department of Agriculture. 2014. Floriculture crops 2013 summary. 10 Sept. 2016. <http://www.nass.usda. gov/Statistics_by_State/New_Jersey/ Publications/Floriculture_Statistics / FlorCrop-06-19-2014.pdf>.

van der Gaag, D.J., A. Kerssies, and C. Lanser. 2001. Spread of phytophthora root and crown rot in saintpaulia, gerbera and spathiphyllum pot plants in ebb-andflow-systems. Eur. J. Plant Pathol. 107:535-542.

van der Plaats-Niterink, A.J. 1981. Monograph of the genus Pythium. Centraalbureau voor Schimmelcultures Baarn, Utrecht, The Netherlands.

Vuik, J., J.M. Van der Poll, R. Vink, and R.H. De Vos. 1990. Adsorption experiments of etridiazole and oxamyl on polyethylene sheets and poly (vinyl chloride) tubing used in horticulture. J. Agr. Food Chem. 38:328-330.

Warncke, D. and D.M. Krauskopf. 1983. Greenhouse growth media: Testing and nutrition guidelines. Michigan State Univ. Ext. Bul. E-1736.

Wolfe, N.L., R.G. Zepp, J.C. Doster, and R.C. Hollis. 1976. Captan hydrolysis. J. Agr. Food Chem. 24:1041-1045.

Zheng, J., J.C. Sutton, and H. Yu. 2000. Interactions among Pythium aphanidermatum, roots, root mucilage, and microbial agents in hydroponic cucumbers. Can. J. Plant Pathol. 22:368-379. 